\title{
Cytogenetic study of embryos from ducks maintained in conservative flocks
}

\author{
K. Jaszczak ${ }^{1,3}$, J. Książkiewicz ${ }^{2}$, R. Parada ${ }^{1}$ and M. Sacharczuk ${ }^{1}$ \\ ${ }^{1}$ Department of Molecular Cytogenetics, Institute of Genetics and Animal Breeding, \\ Polish Academy of Sciences \\ Jastrzębiec, 05-552 Wólka Kosowska, Poland \\ ${ }^{2}$ Department of Waterfowl Breeding, National Research Institute of Animal Production Dworzyska \\ 1, 62-035 Kórnik, Poland
}

(Received 31 March 2004; revised version 18 March 2005; accepted 4 August 2005)

\begin{abstract}
Conservative flocks are usually small populations in which inbreeding and mutations may result in unfavourable changes. With this aim, studies were conducted on the karyotypes of duck embryos $(40 \mathrm{~h})$ from four conservative flocks: $\mathrm{KhO}, \mathrm{A} 3, \mathrm{O} 1, \mathrm{LSA}$, maintained since the seventies as closed flocks. A total of 336 embryos were examined of which $27(8 \%)$ had an abnormal chromosome complement. The frequency of embryos with chromosome abnormalities varied from $4.9 \%$ in the A3 flock to $13.7 \%$ in the LSA flock. In the two remaining flocks, (KhO and O1) the frequency was 5.9 and 6.6, respectively. Pure haploidy and haploid/diploid chimerism were the most frequently identified abnormalities in all flocks examined.
\end{abstract}

KEY WORDS: embryos, chromosome abnormalities, conservative flock, ducks

\section{INTRODUCTION}

Maintenance of animals in closed populations is frequently practised in poultry breeding, particularly in view of preserving as genetic resources of indigenous and disappearing breeds, varieties and strains. In these usually small populations inbreeding and mutations may increased and result in unfavourable changes. Thus cytogenetic studies are a useful tool for the genetic evaluation of such

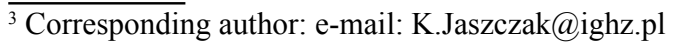


poultry flocks. Cytogenetic investigations of chicken embryos have shown that spontaneous chromosome mutations are often observed mainly in the first days of incubation (Miller et al., 1971; Bloom, 1972; Fechheimer and Jaap, 1980). Both genetic and nongenetic factors have been implicated in the origin of errors during mitosis, meiosis and fertilisation may lead to chromosome aberrations in avian embryos (Fechheimer, 1983; de la Sena et al., 1992).

Most of these chromosomal abnormalities in chicken embryos are responsible for their high mortality and hatching losses (Thorne et al., 1991; Jaszczak and Jaszczak 1993; Hidas et al., 1996). A majority of cytogenetic investigation in poultry concern chicken. While embryos of domestic duck were not object of cytogenetic study till now in spite of that the domestic duck has considerable contribution in poultry meat production on the world. This study aimed at determining the frequency of chromosome abnormalities in embryos from ducks mainting in conservative flocks.

\section{MATERIAL AND METHODS}

The embryos used for karyotyping were from four conservative flocks of ducks designated: $\mathrm{KhO}$ (cross of Khaki Compbell and Orpington ducks), A3 (Pekin type), O1 (Orpington), LSA (synthetic line) created from three preservative flocks of Pekin type. These flocks are maintained since the seventies as closed populations in which a minimum of 25 males and 75 females were used for mating. In each conservative flock and each generation a consistent system of four subgroups was applied. This made possible the rotation of males and thus a decreased rate of relatedness.

The karyotypic examination was carried out during one hatching season. Eggs were collected daily, pedigreed and stored at $12^{\circ} \mathrm{C}$ for two weeks and them placed in an incubator at $38^{\circ} \mathrm{C}$. After $40 \mathrm{~h}$ of incubation eggs were opened and the blastodisks were transferred to culture medium with addition of of colcemide. Further processing with short culture $(3 \mathrm{~h})$, hypotonic solution, fixation and slide preparation followed the method described by Zartman and Jaszczak (1979). Ten to 20 metaphase spreads were analysed by scoring the presence of the largest six pairs of autosomes and sex chromosomes. The two binomial parameters test (Ott, 1984) was used to compare groups of embryos with regard to the incidence of embryos with chromosome abnormalities. 


\section{RESULTS AND DISCUSSION}

In all 539 duck eggs incubated 377 were fertile (69.9\%). Chromosome preparations with well spread metaphases obtained from 336 embryos. Among these embryos $27(8 \%)$ had an abnormal chromosome complement (Table 1). The frequency of embryos with chromosome abnormalities varied from $4.9 \%$ in A3 flock to $13.7 \%$ in LSA flock (difference significant at $\mathrm{P}<0.05$ ). In the two remaining flocks, $\mathrm{KhO}$ and $\mathrm{O} 1$ the frequency of chromosome aberrations was 5.9 and 6.6, respectively. Pure haploidy (1AZ) and haploid/diploid chimerism (1AZ/2A/ZZ) were the most frequency identified abnormalities in all flocks examined. The remaining aberrations included one pure tetraploid (4AZZWW) and two diploid/tetraploid mosaics (2AZZ/4AZZZZ).

TABLE 1

Number and percentage of heteroploid embryos in four examined conservative flocks of domestic duck

\begin{tabular}{|c|c|c|c|}
\hline $\begin{array}{l}\text { Conservative } \\
\text { flock }\end{array}$ & $\begin{array}{l}\text { Number of karyotypic } \\
\text { analysed embryos }\end{array}$ & $\begin{array}{c}\text { Abnormality (number } \\
\text { observed) }\end{array}$ & $\begin{array}{c}\text { Percentage of embryos } \\
\text { with chromosome } \\
\text { abnormalities }\end{array}$ \\
\hline A3 & 81 & $\begin{array}{c}1 \mathrm{AZ} \mathrm{(3)} \\
1 \mathrm{AZ} / 2 \mathrm{AZZ}(1)\end{array}$ & $4.9^{*}$ \\
\hline $\mathrm{KhO}$ & 84 & $\begin{array}{c}1 \mathrm{AZ}(2) \\
1 \mathrm{AZ} / 2 \mathrm{AZZ}(2) \\
2 \mathrm{AZZ} / 4 \mathrm{AZZZZ}(1)\end{array}$ & 5.9 \\
\hline $\mathrm{O} 1$ & 76 & $\begin{array}{c}1 \mathrm{AZ}(4) \\
2 \mathrm{AZZ} / 4 \mathrm{AZZZZ}(1)\end{array}$ & 6.6 \\
\hline LSA & 95 & $\begin{array}{c}1 \mathrm{AZ}(8) \\
1 \mathrm{AZ} / 2 \mathrm{AZZ}(4) \\
4 \mathrm{AZZWW}(1)\end{array}$ & $13.7^{*}$ \\
\hline Total & 336 & 27 & 8.0 \\
\hline
\end{tabular}

It has been reported for chicken that the occurrence of haploid cell lines, either in pure haploidy and in haploid/diploid embryos) was androgenetic, i.e originated from a spermatozoa (Fechheimer, 1990). The occurrence of haploidy in duck embryos is presumably of a similar origin, because only the $\mathrm{Z}$ chromosome was observed. Female sex chromosome $\mathrm{W}$ was not found in the haploidy cell lines. In the ducks studied, two embryos showed tetraploid cell lines and one was pure tetraploid. Tetraploid cells might arise from a failure of cytokinesis during the first cleavage division. 
Data concerning chromosome abnormalities in duck embryos have not yet been reported. A comparison of the frequency of chromosome abnormalities in fertile duck eggs with those of other species of waterfowl indicates, that this phenomenon appears more often in ducks than, for example, in geese. However, in the present study, the type of chromosome abnormalities found in the duck embryos examined was also similar to that reported for geese (Jaszczak et al., 1999). The noticeable difference in the frequency of embryos with chromosome aberrations observed in the synthetic line (LSA flock) can result from the genetic make-up of components used for creating this line. Selected lines or strains of chicken are differ in the frequency of chromosome aberrations (Thorne and Sheldon, 1991; Jaszczak et al., 1992).

The results obtained indicate the value of a cytogenetic testing when aiming at an elimination of the carriers of chromosome aberrations, which may be the reason for embryonic mortality and a decline of fertility in duck flocks. This is especially important in the case of conservative flocks, which are to constitute genetic resources.

\section{REFERENCES}

Bloom S.E., 1972. Chromosome abnormalities in chicken (Gallus domesticus) embryos: types frequencies and phenotypic effect. Chromosoma 37, 309-326

De la Sena C.A., Fechheimer N.S., Nestor K.E., 1992. Evidence for genetic etiology of heteroploidy in embryos of the Japanese quail (Coturnix coturnix japonica). Cytogenet. Cell Genet. 60, $140-145$

Fechheimer N.S., 1990. The domestic chicken (Gallus domesticus) as an organism for the study of chromosomal aberrations. In: V. Pliska, G. Stranzinger (Editors). Farm Animals in Biomedical Research. P. Parey Verlag, Hamburg, Berlin, pp. 43-53

Fechheimer N.S., Isakova G.K., Belyaev D.K., 1983. Mechanisms involved in the spontaneous occurrence of diploid-triploid chimerism in the mink ( Mustela vision) and chicken (Gallus domesticus). Cytogenet. Cell Genet. 35, 238-243

Fechheimer N.S., Jaap R.G., 1980. Origins of euploid chimerism in embryos of Gallus domesticus. Genetica 52/53, 69-72

Hidas A., Szaly I., Liptoi K., Varkonyi E., 1996. Cytogenetic analysis of early dead embryos in chicken breeding stock. Proceedings of the $12^{\text {th }}$ European Colloquium on Cytogenetics of Domestic Animals. Arch. Zootec. 45, 221-224

Jaszczak K., Cywa-Benko K., Wężyk S., 1992. Chromosome abnormalities in early embryos from chicken maintaning in preservable flocks (in Polish). Rocz. Nauk Zoot. 31, 285-294

Jaszczak K., Jaszczak J., 1993. Chromosomal abnormalities in early embryos and commercial chick and hatchability in reproduction flock of layer and broiler hens. Genet. Pol. 34, 287-293

Jaszczak K., Rabsztyn A., Jaszczak J., Kapkowska E., 1999. A karyotypic survey of early goose embryos. Anim. Sci. Pap. Rep. 17, 67-72

Miller R.C., Fechheimer N.S., Jaap R.G., 1971. Chromosome abnormalities in 16- to 18-hour chick embryos. Cytogenetics 10, 121-136 
Ott L., 1984. An Introduction to Statistical Methods and Data Analysis. Boston: Duxburg Press, Boston

Thorne M.H., Collins R.K., Sheldon B.L., 1991. Chromosome analysis of early embryonic mortality in layer and broiler chickens. Brit. Poultry Sci. 32, 711-722

Thorne M.H., Sheldon B.L., 1991. Cytological evidence of maternal meiotic errors in a line of chickens with a high incidence of triploidy. Cytogenet. Cell Genet. 57, 206-210

Zartman D., Jaszczak K., 1979. A procedure for chromosome preparations from early chick embryos. Pr. Mat. Zoot. 23, 115-118

\section{STRESZCZENIE}

\section{Badania kariotypowe zarodków kaczek utrzymywanych w stadach zachowawczych}

Stada zachowawcze są najczęściej małymi populacjami, w których inbred i mutacje chromosomowe moga powodować niekorzystne zmiany. W tym celu przeprowadzono badania kariotypowe zarodków kaczek (40 godz.) pochodzących z czterech stad zachowawczych: Kho, A3, 01, LSA. Wśród badanych kariotypowo łącznie 336 zarodków, u $27(8,0 \%)$ wystąpiły nieprawidłowości chromosomowe. Stwierdzono duże zróżnicowanie w częstotliwości występowania nieprawidłowości chromosomowych między badanymi stadami kaczek: od 4,9\% w stadzie A3 do 13,7\% w stadzie LSA. W dwóch pozostałych, KhO i 01, stwierdzono odpowiednio 5,9 i 6,6\% zarodków z aberracjami chromosomowymi. Wśród nieprawidłowości kariotypowych występowały głównie: haploidia i chimeryzm haploidalno-diploidalny oraz w dwóch przypadkach mozaikowatość 2AZZ/4AZZZZ i u jednego zarodka czysta tetraploidia 4A/ZZZZ. 